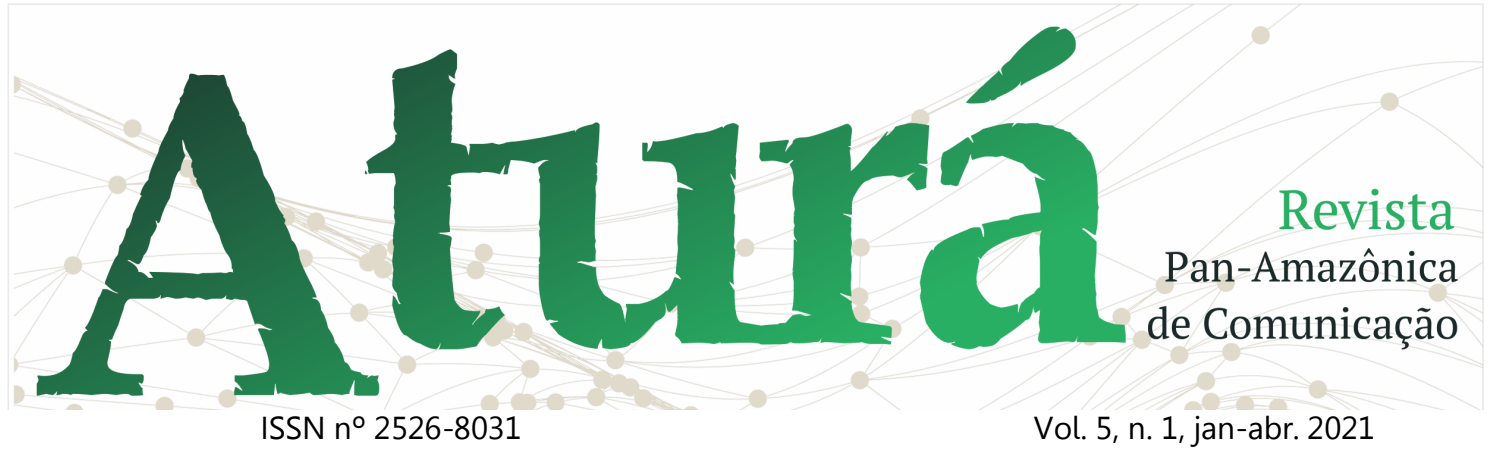

\title{
IGUALDADE NA DIFERENÇA: REPRESENTAÇÕES IDENTITÁRIAS NOS DOCUMENTÁRIOS LIMITADO, EU? E A INTOLERÂNCIA QUE MATA DA TV ALE-RR
}

Equality in difference: identity representations in the documentaries Limited, me? and The intolerance that kills from TV ALE-RR

Igualdad en la diferencia: representaciones de identidad en los documentales Limitado, yo? y La intolerancia que mata de TV ALE-RR

Sonia Lucia Nunes Pinto, Universidade Federal de Roraima ${ }^{1}$

\section{RESUMO}

O presente trabalho busca analisar a TV Assembleia Legislativa de Roraima (TV institucional de caráter público) nas suas produções de sentidos. Para isso, observa-se a construção dos discursos de cidadania e de identidade política inclusiva para além da tela da TV, por meio dos documentários Limitado, eu? e $A$ intolerância que mata, produzidos pelo jornalista Rubens Medeiros, em 2018. Os aportes teórico-metodológicos utilizados tratam sobre Estudos Culturais (identidade, cultura), pós-coloniais e meios de comunicação de massa. Até o momento, constatou-se que a construção identitária é resultado das práticas sociais no processo comunicacional, em que os significados são instituídos pela sociedade, como uma visão de si mesma.

PALAVRAS-CHAVE: Audiovisual; Igualdade; Diferença; Identidade; TV Assembleia.

\section{ABSTRACT}

The present work seeks to analyze the TV Legislative Assembly of Roraima (institutional TV of public character) in its production of meanings. For this, the construction of discourses of citizenship and inclusive political identity is observed beyond the TV screen, through the documentaries Limited, me? and The intolerance that kills, produced by journalist Rubens

\footnotetext{
${ }^{1}$ Mestranda em Comunicação pela Universidade Federal de Roraima, especialista em Política e Representação Parlamentar pelo Centro Universitário de Ensino Superior do Amazonas (Ciesa) e Bacharel em Comunicação Social - habilitação em Jornalismo (UFRR). Jornalista na Assembleia Legislativa de Roraima. E-mail: sonialnunes@gmail.com
} 


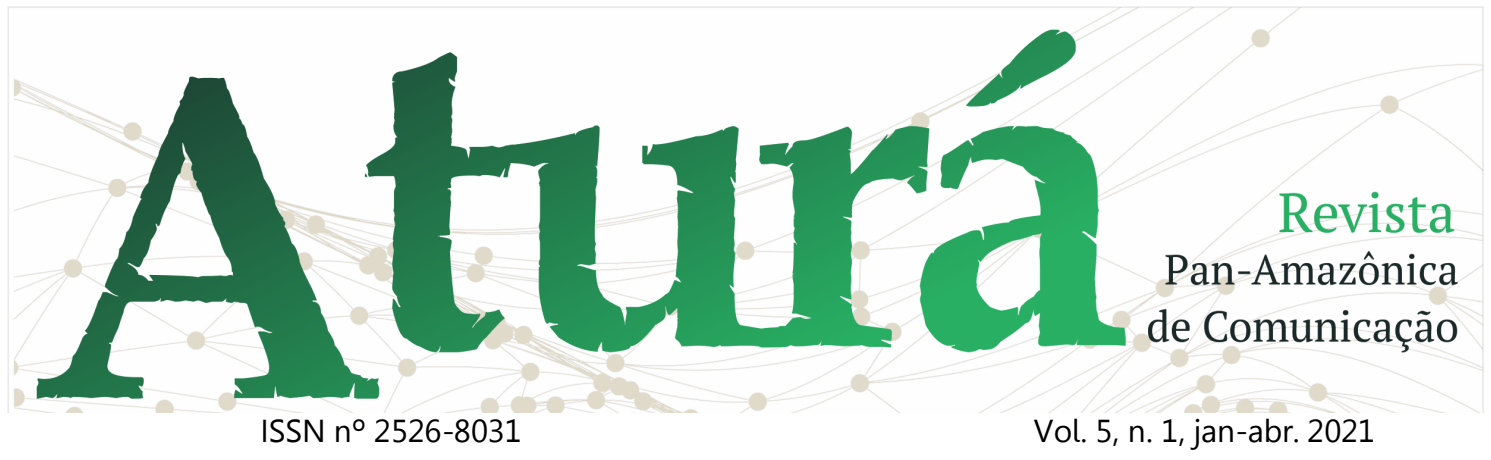

Medeiros, in 2018. The theoretical and methodological contributions used deal with Cultural Studies (identity, culture), post-colonial and mass media. So far it has been found that identity construction is the result of social practices in the communicational process, in which meanings are instituted by society, as a view of itself.

KEYWORDS: Audio-visual; Equality; Difference; Identity; TV Assembly.

\section{RESUMEN}

El presente trabajo busca analizar la TV Asamblea Legislativa de Roraima (TV institucional de carácter público) en su producción de significados. Para ello, la construcción de discursos de ciudadanía e identidad política inclusiva se observa más allá de la pantalla de televisión, a través de los documentales ¿Limitado, yo? y La intolerancia que mata, elaborado por el periodista Rubens Medeiros, en 2018. Los aportes teóricos y metodológicos utilizados versan sobre los Estudios Culturales (identidad, cultura) y los medios de comunicación poscoloniales. Hasta ahora se ha encontrado que la construcción de la identidad es el resultado de prácticas sociales en el proceso comunicacional, en el que los significados son instituidos por la sociedad, como una visión de sí misma.

PALABRAS CLAVE: Audiovisual; Igualdad; Diferencia; Identidad; TV Asamblea. 


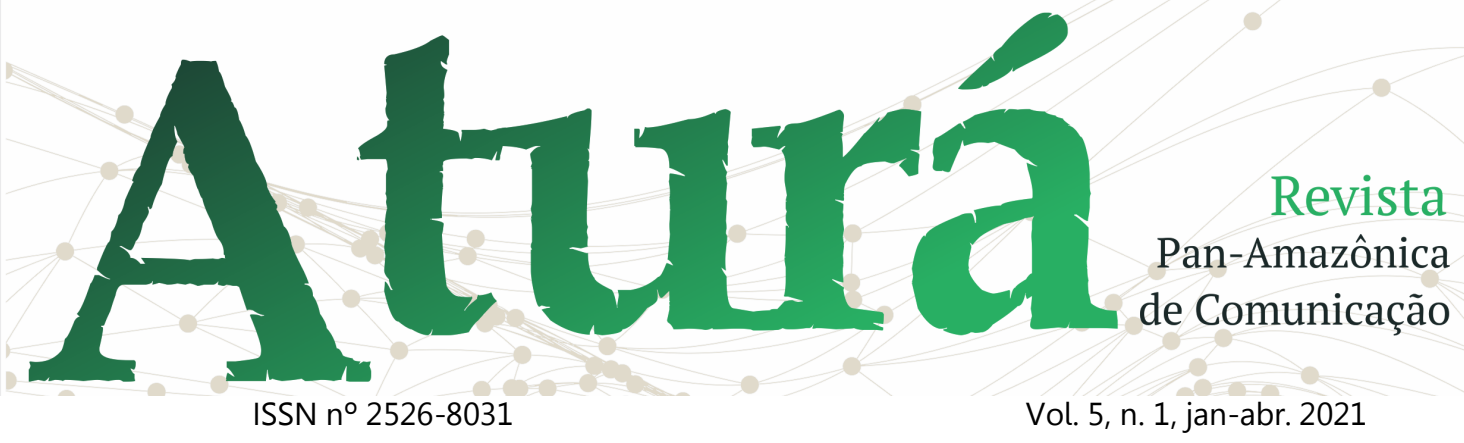

\section{Introdução}

As políticas públicas de inclusão da pessoa com deficiência são recentes e se fortaleceram com o surgimento da Lei $\mathrm{n}^{\circ}$ 13.146, de 6 de julho de 2015, conhecida como Estatuto da Pessoa com Deficiência. Ainda assim, essa parcela da população é classificada como inválida, incapacitada, minorada, impedida, descapacitada e excepcional.

Não diferente, a população LGBT (Lésbicas, Gays, Bissexuais, Travestis, Transexuais e Transgêneros), embora tenha conquistado avanços em 2001, com a criação do Conselho Nacional de Combate à Discriminação e Promoção dos Direitos de Lésbicas, Gays, Bissexuais, Travestis e Transexuais (CNCD-LGBT), é vítima constante da discriminação e violência por causa da orientação ou da designação sexual.

A Constituição Federal do Brasil, no artigo $5^{\circ}$, diz que "todos são iguais perante a lei, sem distinção de qualquer natureza" e afirma ainda, no artigo $3^{\circ}$, que um dos objetivos fundamentais do país é "promover o bem de todos, sem preconceitos de origem, raça, sexo, cor, idade e quaisquer outras formas de discriminação". No entanto, em pleno século 21 , ações de defesa, proteção e garantias dos direitos das pessoas com deficiência e LGBT se mostram ineficientes e vivem um retrocesso no atual governo.

Os meios de comunicação não estão livres de praticar preconceitos, mas devem ter uma responsabilidade de combater paradigmas e fomentar a cultura da inclusão, do respeito às diferenças $e$ fortalecer a democracia. Sendo assim, o objetivo deste artigo é analisar de que forma a TV Assembleia Legislativa de Roraima, instalada em agosto de 2015, articula a produção de sentido para construir um discurso de cidadania, de uma identidade política inclusiva para além da tela da TV, por meio dos documentários Limitado, eu? e a Intolerância que mata, produzidos pelo jornalista Rubens Medeiros, em 2018.

Para compreender como se dá esse processo, o artigo traz, além de pesquisas bibliográficas e abordagem qualitativa, os Estudos Culturais (identidade e cultura) e pós-coloniais para responder a problemática aqui levantada. As 


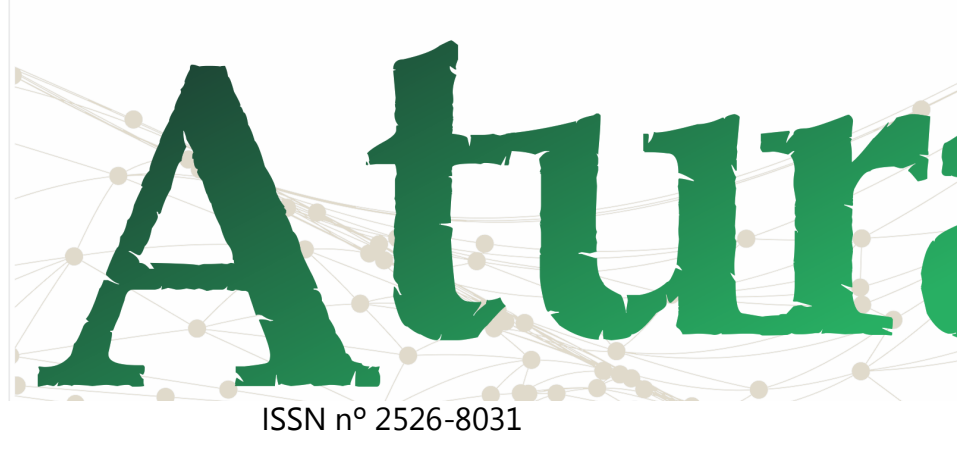

proposições apontadas revelam que a construção identitária é resultado das práticas sociais no processo comunicacional, em que os significados são instituídos pela sociedade, como uma visão de si mesma.

\title{
Pessoa com deficiência e política de inclusão
}

Durante muito tempo, as pessoas com algum tipo de deficiência eram denominadas de incapacitadas, inválidas e portadoras de deficiência, terminologias não mais aplicáveis hoje em dia. Tratavase de uma forma excludente de tratamento, amenizada na contemporaneidade por leis que garantem a essas pessoas o direito à inclusão na sociedade e a uma participação mais atuante nas questões que thes dizem respeito, sendo vozes ativas nas decisões em prol de uma coletividade que requerem sobremaneira meios que facilitem sua convivência em comunidade, sem a necessidade de exclusiva dependência de terceiros para ações do dia a dia.

Revista Pan-Amazônica de Comunicação Vol. 5, n. 1, jan-abr. 2021

A Lei $n^{\circ}$ 13.146, de 6 de julho de 2015, conhecida como Estatuto da Pessoa com Deficiência, traz o seguinte conceito no Art. $2^{\circ}$ :

\begin{abstract}
Considera-se pessoa com deficiência aquela que tem impedimento de longo prazo de natureza física, mental, intelectual ou sensorial, o qual, em interação com uma ou mais barreiras, pode obstruir sua participação plena e efetiva na sociedade em igualdade de condições com as demais pessoas (BRASIL, 2015, art. 2).
\end{abstract}

Diversos termos foram usados por um longo período para classificar as pessoas com deficiência: inválidos, incapacitados, minorados, impedidos, descapacitados, excepcionais. A partir de 1962, começou a haver uma evolução, quando, nos Estados Unidos, deu-se início a um movimento pelos direitos das pessoas com deficiência, tendo sido criado, na mesma época, o primeiro Centro de Vida Independente em todo o mundo.

No Brasil, com a Constituição Brasileira de 1967, a partir da Emenda Constitucional $n^{\circ} 1 / 1969$, foi introduzido o uso do termo "deficiente". Com a Emenda Constitucional no 12/1978, estabelece-se a garantia de acesso aos espaços públicos, 


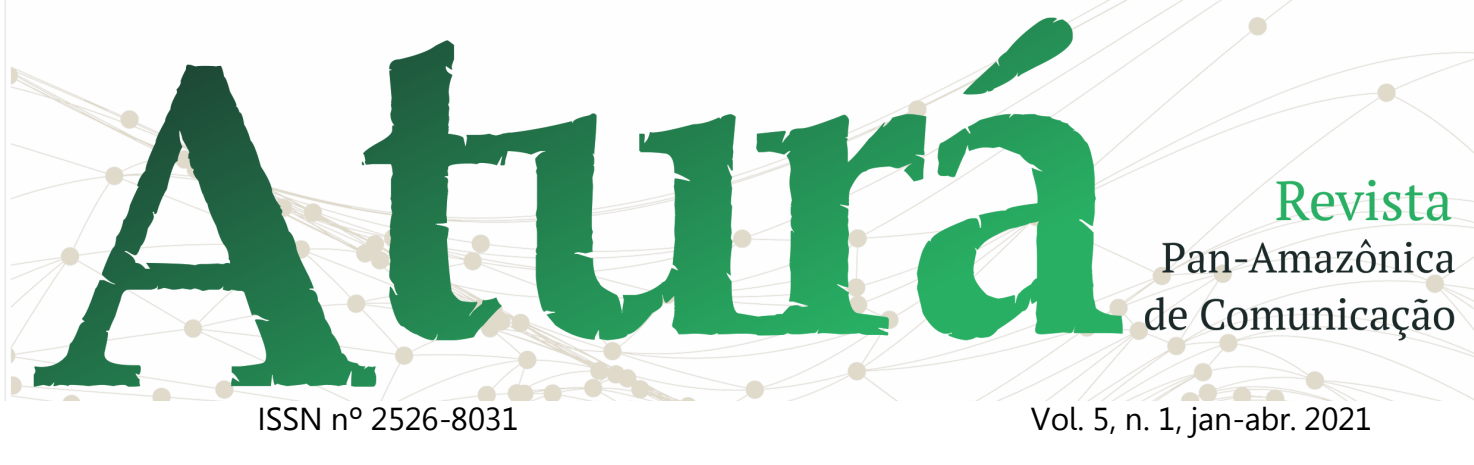

além da proibição dos preconceitos e das discriminações. Em 1988, a Constituição Brasileira modificou o termo "deficiente" para a expressão "pessoa portadora de deficiência", sendo em seguida alterada para "pessoas com deficiência", usada atualmente.

Foram várias as convenções internacionais, das quais o Brasil é signatário, que influenciaram o país e ajudaram a lidar com o tema. Como destacado no início, existe atualmente um forte arcabouço legal que dispõe sobre a inclusão social das pessoas com deficiência. Mas, no dia 26 de novembro de 2019, o presidente da República, Jair Bolsonaro, protocolou na Câmara Federal o Projeto de Lei 6159/19, que flexibiliza a Lei de Cotas, que há mais de duas décadas tem contribuído para a inserção de pessoas com deficiência no mercado de trabalho. A medida, caso seja aprovada, desobriga as empresas com 100 ou mais empregados, de reservar entre $2 \%$ a $5 \%$ dos seus cargos para contratação de pessoas com deficiência.

Além da resistência para manutenção e garantia de políticas públicas já executadas no país, é preciso haver uma modificação nas relações pessoais, o que passa pela educação, para que as intenções saiam do papel e a inserção realmente aconteça no mercado de trabalho e nas escolas.

Na mídia, essa representatividade das pessoas com deficiência é rara. E a imagem retratada há muito tempo era a de "coitadas". Uma realidade desnaturalizada. Certamente, temos meios de comunicação que se preocupam em desmitificar a deficiência. É de senso comum que, ao não se resolverem os problemas no trato com as pessoas com deficiência, é a sociedade que se "limita" por não ter derrubado ainda paradigmas que já deveriam ter sido abolidos há muito tempo.

\section{População LGBT e a luta constante por respeito}

Foi no final da década de 1960, nos Estados Unidos, que surgiu o primeiro movimento em favor dos direitos da população LGBT no mundo. O episódio foi marcado por uma série de manifestações promovidas por homossexuais contra 


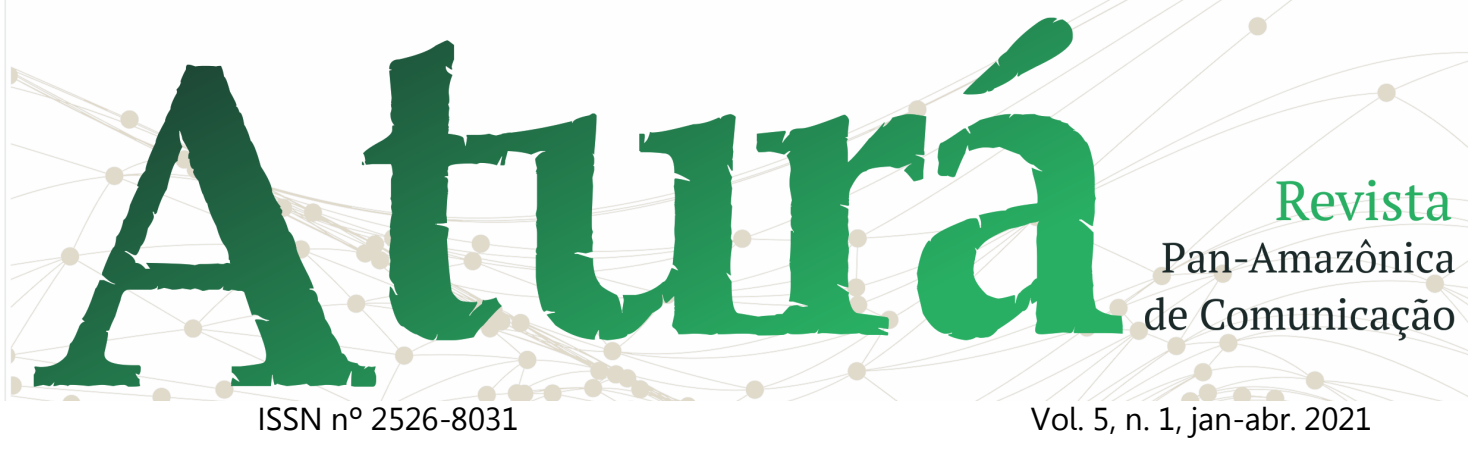

ações truculentas da polícia, durante batidas no bar Stonewall Inn, localizado em Nova York.

A sigla LGBT se refere a lésbicas, gays, bissexuais, travestis e transexuais. Conforme a pesquisadora Regina Facchini, o $T$, do movimento homossexual, também está relacionado a transgêneros, "pessoas cuja identidade de gênero não se alinha de modo contínuo ao sexo que foi designado no nascimento (crossdressers, drag queens, transformistas, entre outros)". (FACCHINI, 2011, p. 10). No Brasil, o movimento LBGT surge nos anos 1970, no embalo dos movimentos feministas e negro.

Em 2001, é criado o Conselho Nacional de Combate à Discriminação e Promoção dos Direitos de Lésbicas, Gays, Bissexuais, Travestis e Transexuais, que faz parte da estrutura do governo federal, na Secretaria Especial de Direitos Humanos. Foi idealizado para estabelecer políticas públicas de combate à discriminação e defesa dos direitos da comunidade LGBT.

No governo Lula, em 2004, o movimento ganha destaque com 0 lançamento do Programa Brasil sem

Homofobia. Quatro anos depois, é realizada a $1^{\text {a }}$ Conferência Nacional LGBT, com o tema: Direitos humanos e políticas públicas: o caminho para garantir a cidadania LGBT. O encontro resultou no Plano Nacional de Promoção da Cidadania e Direitos Humanos de Lésbicas, Gays, Bissexuais, Travestis e Transexuais. Em 2011, o governo federal promove a segunda conferência. Nesse mesmo ano, a Justiça, leia-se Supremo Tribunal Federal, reconhece a união estável para pessoas do mesmo sexo. Uma vitória do movimento.

Outra conquista, em meio à crescente onda de violência contra a população LGBT, foi a decisão do STF, em 13 de junho de 2019, de criminalizar a homofobia como forma de racismo. Ou seja, enquanto o Congresso Nacional não aprovar legislação especifica que puna casos de agressões contra a população LGBT, as ocorrências serão configuradas como crime de racismo. Um ano depois da decisão do Supremo, no dia 14 de setembro de 2020, o governo Bolsonaro recorre da decisão por meio de um recurso interposto pela Advocacia-Geral da União (AGU). 


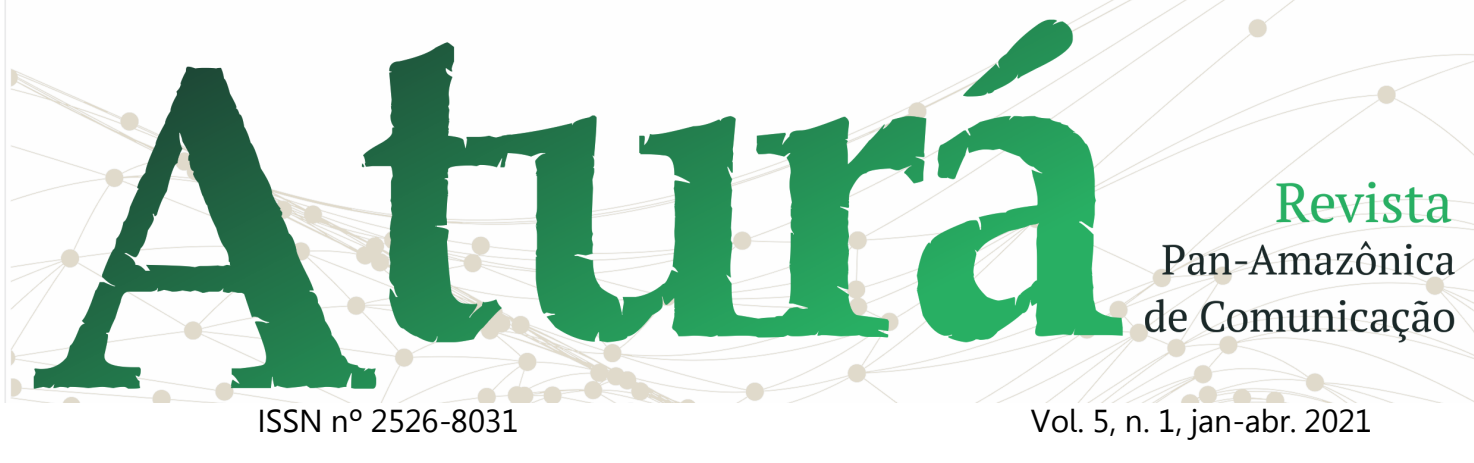

Dados do Grupo Gay da Bahia (GGB) apontam que, em 2018, 420 pessoas morreram vítimas de homolesbotransfobia ${ }^{2}$, sendo $76 \%$ homicídios e $24 \%$ suicídios. Os homens gays representam 39\% das vítimas, seguidos das transexuais, 36\%. Já as mulheres lésbicas ocupam o terceiro lugar nas estatísticas, 12\%, e bissexuais, 2\%. Roraima está em $6^{\circ}$ lugar no índice de assassinatos de LGBT. O relatório anual de mortes LGBTI+ de 2018 deixa claro que os casos podem ser maiores, devido à taxa de subnotificação.

Atualmente, os meios de comunicação, novelas e programas de auditório abordam a homossexualidade com mais respeito, até mesmo porque os movimentos em defesa da população LGBT têm lutado rotineiramente para romper com os preconceitos, discriminação e cobrado punição para os casos de violência e, dessa forma, garantir o direito à diversidade. $\mathrm{O}$ "politicamente correto" - utilizado de forma pejorativa por aqueles que não reconhecem seu

semelhante que tem orientações e identidade de gênero diversas, deve prevalecer com o sentido real da palavra, que é fomentar o respeito e combater o preconceito, discriminação e ofensas.

\section{TV Assembleia como produtora de} sentidos e identidade sob a ótica dos Estudos Culturais

Os meios de comunicação ligados ao Poder Legislativo surgiram por meio da Lei 8.977, de 6 de janeiro de 1995, que dispõe sobre o serviço de TV a cabo, com o objetivo de divulgar as ações parlamentares, especialmente a transmissão ao vivo das sessões.

Em Roraima, o primeiro canal institucional do Poder Legislativo começou a operar no dia 7 de agosto de 2015. A TV Assembleia Legislativa de Roraima, canal 57.3, foi ao ar pela primeira vez já em formato digital, após a assinatura de um protocolo de intenções entre a Assembleia Legislativa e o Senado Federal, em julho de 2012.

\footnotetext{
2 Homolesbotransfobia é a junção das palavras: homofobia, lesbofobia e transfobia.
} 


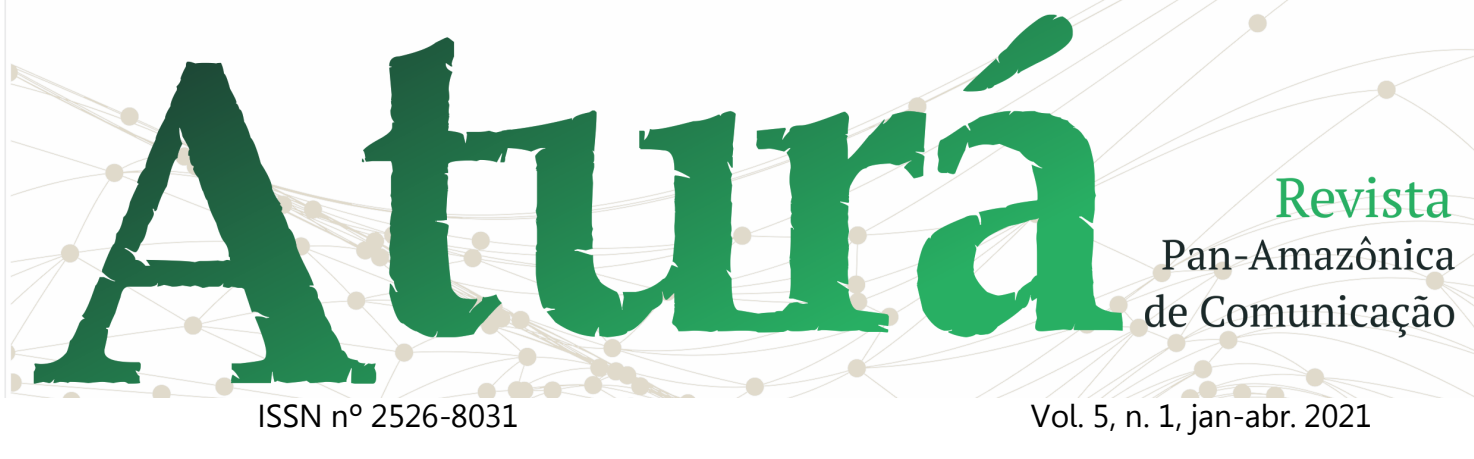

Atualmente, a emissora tem à disposição 24 horas de programação que são preenchidas com produções próprias, conteúdo da TV Senado e outras TVs legislativas parceiras, além de veicular material acadêmico e institucional de outros Poderes. Entre as produções locais, citamos os programas Sessão Ao Vivo, jornal Assembleia Informa, Em Pauta, Resumo da Semana, Boletim Informativo, Parlamento por Dentro, Parlamento em 1 Minuto, programa 3 Minutos com 0 Deputado, Cabine Brasil e ALE Musical. A TV Assembleia tem investido também em reportagens especiais e documentários.

A partir dessa produção midiática, a TV Assembleia constrói uma identidade que vai além das atribuições de uma emissora institucional. Os Estudos Culturais, como corrente de estudo na contemporaneidade, explicam esse fenômeno. Junior e Gomes (2011, p. 7) afirmam que aqueles "são caracterizados por um certo modo de olhar (ou de abordar) os fenômenos sociais".

Nessa perspectiva, nos Estudos Culturais, a realidade e identidade são construções sociais e as crenças são

baseadas em percepções da realidade em busca de entender a sociedade. O receptor - cidadão que consome os produtos culturais - não é visto como um papel em branco passível de influência de tudo que recebe, como prega a Escola de Frankfurt, mas, sim, um sujeito capaz de pensar e interpretar as mensagens.

Para Martín-Barbero (1997), esse sentido é construído por meio do processo de se repensar a comunicação a partir das práticas sociais. Isso nos leva a entender que as mediações sociais são decisivas para determinar como se realiza - processo comunicacional em cada sociedade. "Assim, trata-se da comunicação nas ruas, nas casas, nas praças, nas festas, nos bairros, nas escolas, nas famílias; entre mulheres, jovens, indígenas, trabalhadores rurais, domésticas etc." (ESCOSTEGUY, 2010, p. 105-106).

A partir das mediações sociais, as pessoas se relacionam com a comunicação de massa, estabelecendo negociações simbólicas a partir da oferta proposta pelos veículos, mas também de sua visão de mundo, de seus hábitos e crenças. 


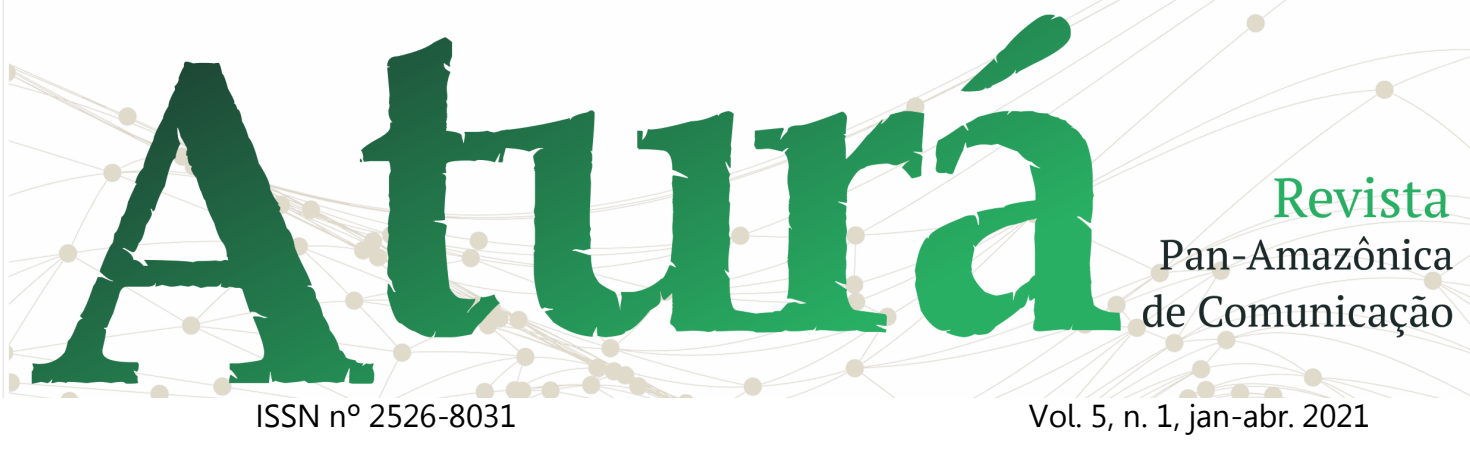

Forma-se aí a identidade cultural, considerada o eixo central dos Estudos Culturais de hoje. Escosteguy (2010, p. 145) dialoga com Hall (2013) e concorda que identidade "passa a ser encarada como algo sujeito à mudança e inovações".

Para Hall (2013, p. 109), os processos de globalização e imigração, sejam eles forçados ou "livres", explicam a dialética sobre "quem nós somos ou de onde viemos". O cerne dessa questão não é exatamente isso. Tem a ver com outros questionamentos.

Quem podemos nos tornar, como nós temos sido representados e como essa representação afeta a forma como nós podemos representar a nós próprios". [..] as identidades são construídas dentro e não fora do discurso que nós precisamos compreendê-las como produzidas em locais históricos e institucionais específicos, no interior de formações e práticas discursivas específicas, por estratégias e iniciativas especificas. (HALL, 2013, p. 109)

E sua construção ocorre por meio das diferenças. Ou seja, "é apenas por meio da relação com o Outro" (HALL, 2013, p. 110), do modo de interagir, que elas são estruturadas no processo comunicacional.

Hall (2003), ao considerar alguns conceitos pós-coloniais, reforça que nenhuma sociedade, seja local ou de "fora", pode se desenvolver sem levar em consideração a relação com o "outro", dentro da cadeia discursiva.

Nessa construção, os meios de comunicação são protagonistas na formação das/e novas identidades culturais. A TV Assembleia Legislativa de Roraima surgiu com uma proposta cidadã, uma vez que a população pode acompanhar as sessões plenárias, ao vivo, além de seguir, por meio de sua programação, assuntos de interesse dos roraimenses. A emissora tem buscado a participação popular e a quebra de paradigmas ancorados no preconceito e discriminação de classes.

A estrutura discursiva dos documentários Limitado, eu? e Intolerância que mata revela essa assertiva e nos remonta novamente ao que os Estudos Culturais consideram como práticas sociais. Essas assumem papel importante na "reprodução, manutenção ou transformação das representações que as pessoas fazem e das relações e 


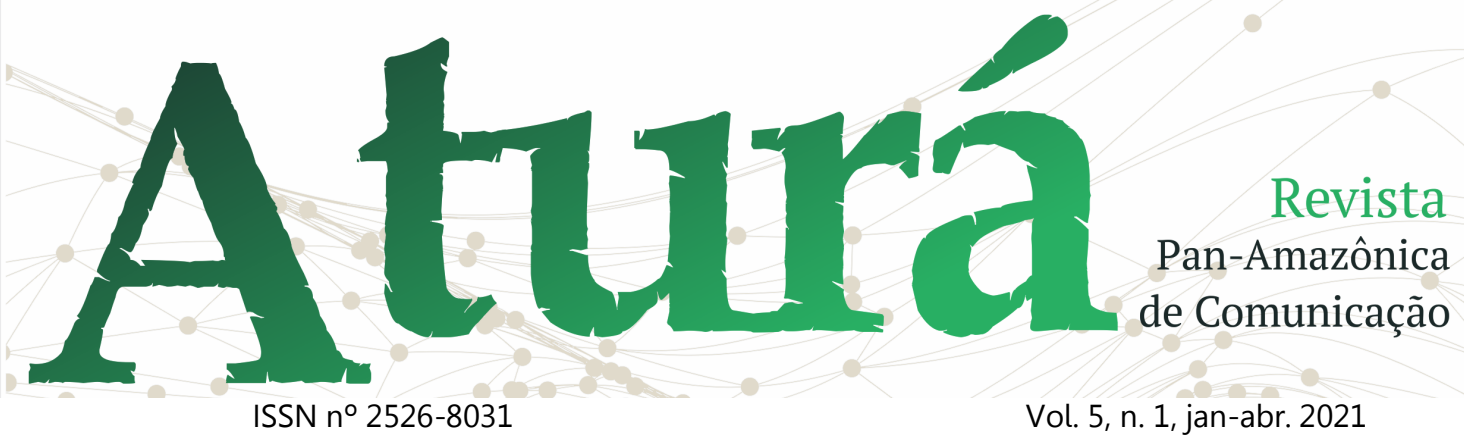

identidade com que se definem na sociedade" (PINTO, 2002, p. 28).

É por meio das narrativas que 0 receptor se reconhece ou não nos discursos hegemônicos produzidos no processo comunicacional dos meios de comunicação. Nessa perspectiva analítica, a emissora, ora descrita aqui, caminha na construção/formação identitária de significados sociais e políticas inclusivas, caracterizada pelo método de visibilidade e diferenciação entre os sujeitos retratados nos documentários, levando em consideração 0 processo de pertencimento de cada cidadão, ou seja, o contexto em que ele vive, que inclui características sociais, econômicas e políticas, assim como étnicas, relações de gênero e sexualidade.

\section{Limitação: a prova de capacidade precisa} ser constante

O documentário Limitado, eu?, produzido pelo jornalista Rubens Medeiros em março de 2018, tem 28 minutos e 12 segundos de duração. A reportagem, exibida na programação diária da TV Assembleia, canal 57.3, e

disponível na página da Assembleia Legislativa de Roraima no YouTube, traz uma narrativa sobre pessoas com deficiência que precisam diariamente provar que são capazes de fazer algo e se manter no mercado de trabalho. Ao lado delas, somam-se $24 \%$ da população brasileira, "ou seja: a cada quatro cidadãos brasileiros em idade laboral, praticamente um precisa provar o tempo inteiro que é capaz de fazer algo", diz trecho do documentário.

A matéria traz dados do Instituto Brasileiro de Geografia e Estatística (IBGE). Em Roraima, cerca de 95 mil pessoas possuem algum tipo de deficiência motora, auditiva, visual, mental ou intelectual. Esse índice associado ao mercado de trabalho gera um abismo. Informações do Ministério do Trabalho e Emprego (2016) mostram que pouco mais de 500 pessoas com deficiência foram contratadas no Estado.

"Por outro lado, o Sine Roraima diz que, em 2018, 1.230 empresas constam como ativas no sistema, e estão aptas a contratar esses profissionais. Se a oferta de trabalho é maior do que a demanda, há 


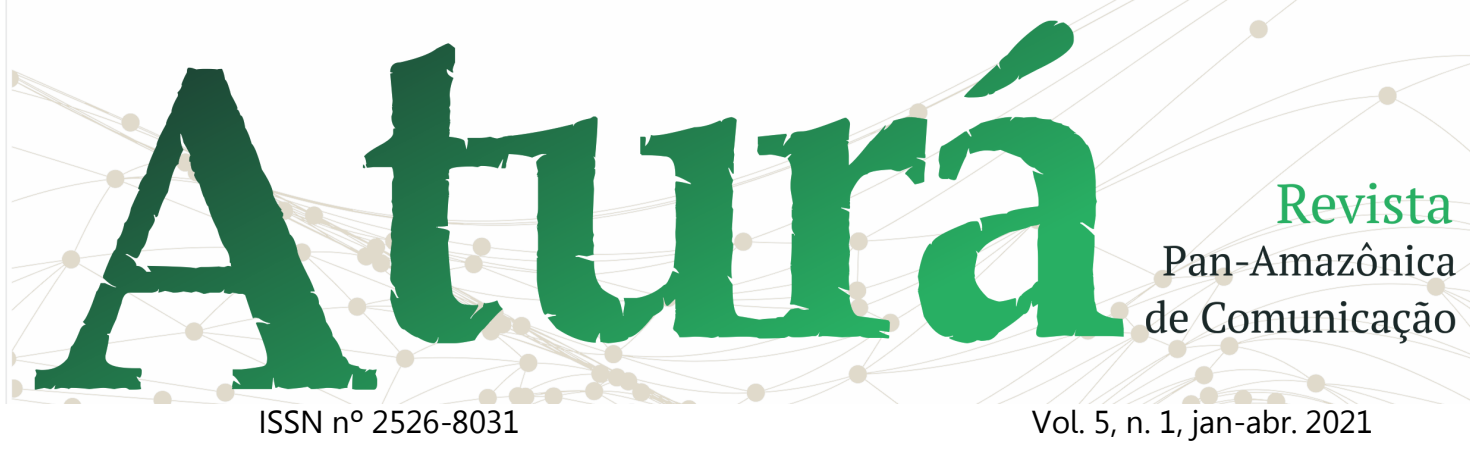

algo inverso por aí" (MEDEIROS, 2018). É nessa narrativa que fica claro que as barreiras impostas pelo preconceito e discriminação são fatores impeditivos de maior inserção das pessoas com deficiência no mercado local.

No documentário, o jornalista entrevista a auditora fiscal do MTE Thaís Castilho. Ela explica que em Roraima poucas empresas são obrigadas a contratar pessoas com deficiência, com base na Lei 8.213 de 24 de julho de 1991, que determina que as empresas com mais de cem trabalhadores devem ter em seus quadros de $2 \%$ a $5 \%$ de pessoas com deficiência. "Esse é o único dispositivo legal que assegura a presença dessa parcela considerável da população no mercado de trabalho. Com poucas garantias, obsoleta em alguns aspectos, ela ainda é a única forma de acesso para esses profissionais", contextualiza o jornalista Medeiros no documentário. Vêse aqui a utilização de um discurso ideológico e identitário de que o Poder Público precisa fazer mais para garantir a inclusão.

[...] o ideológico é uma dimensão necessária de todos os discursos, responsável pela produção de qualquer sentido social, o da ciência, inclusive -, e o que define ideologia como um repertório de conteúdos, opiniões, atitudes ou representações - pois o ideológico é principalmente um mecanismo formal de investimento de sentidos em matérias significantes (PINTO, 2002, p. 46).

A reportagem também narra a história daqueles que, cansados de esperar por uma oportunidade ou esperar do Poder Público uma colocação no mercado de trabalho, resolveram empreender. Conta também o protagonismo dos que se dedicaram aos estudos e ingressaram no serviço público por meio de concurso. Mas ainda são poucos os que conseguem ocupar esses espaços. Por isso, fazendo um link com o Parlamento Estadual, a reportagem traz uma entrevista com o então presidente da Comissão de Defesa dos Direitos da Pessoa com Deficiência da Assembleia Legislativa de Roraima, Valdenir Ferreira, que diz que a sensibilização da classe empresarial é o primeiro passo para quebrar as limitações do preconceito. $\mathrm{E}$ segue o raciocínio de que somente a 


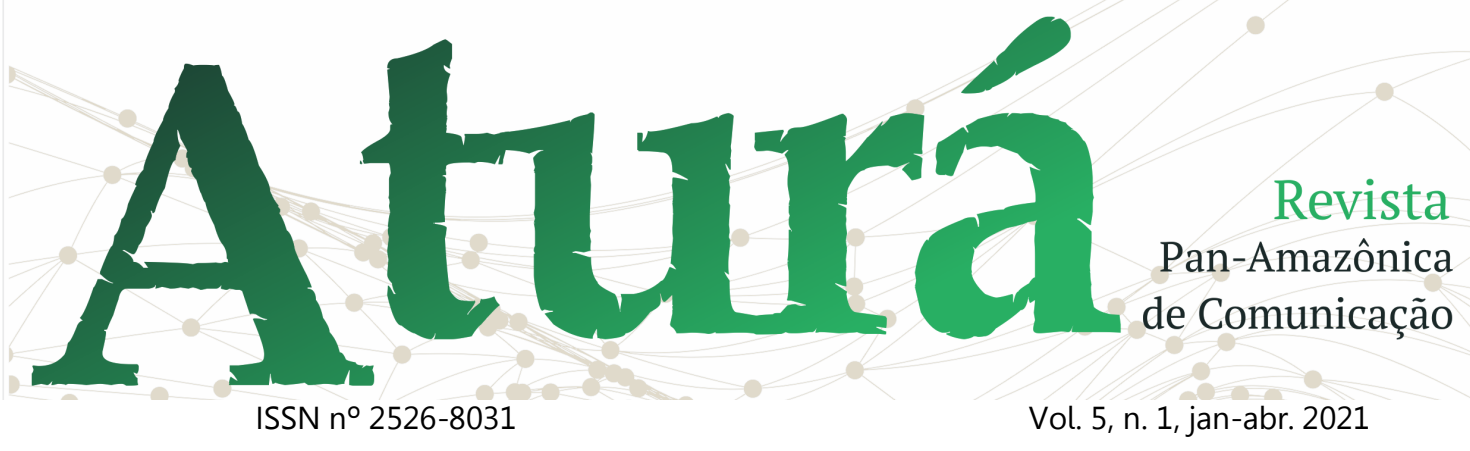

oportunidade é capaz de trazer os resultados que se buscam.

E como dito no início dessa pesquisa, a TV Assembleia, criada com o objetivo de divulgar as ações do Parlamento, se apropriou do espaço que the cabe e elencou as leis que foram aprovadas pela Assembleia Legislativa de Roraima e que têm a intenção de levar dignidade e qualidade de vida para as pessoas com deficiência. São elas: Lei 305, de 2001, que concede o passe livre à pessoa com deficiência no transporte intermunicipal de passageiros; Lei 353, de 2002, que reconhece a Língua Brasileira de Sinais no âmbito estadual; Lei 355, de 2002, que dá preferência à pessoa com deficiência na aquisição de unidades habitacionais; Lei 396, de 2003, que institui a Tarifa Social de Água; Lei 753, de 2009, que cria o Conselho Estadual dos Direitos da Pessoa com Deficiência; Lei 886, de 2013, que assegura que as contas de telefone, água e luz dos deficientes visuais sejam impressas em braile; Lei 1037, de 2016, na qual os concursos públicos precisam ser adaptados à pessoa com deficiência; Lei 1.162, de 2017, que obriga

os cinemas do Estado a abrirem sessões de filmes com acessibilidade para todos; e a Lei 1.184, de 2017, que cria o Fundo Estadual para a Pessoa com Deficiência.

O formato do documentário destaca o protagonismo do Legislativo local, mas, principalmente, nos personagens que assumem também um papel de mediadores das práticas sociais na produção do texto. A narrativa reforça que a superação do preconceito pode ocorrer quando a própria sociedade "abraçar" a causa, que deve começar não somente dentro do lar, mas nas escolas e nos espaços públicos, na identificação e reconhecimento da pessoa com deficiência. Não pela deficiência em si, mas como pessoas. Hall (2013, p. 126) discorre que "Foucault fez um avanço considerável ao mostrar como isso se dá, em conexão com práticas discursivas historicamente específicas, como a autorregulação normativa e com tecnologias do eu".

[...] a questão que fica é se nós também precisamos, por assim dizer, diminuir o fosso entre os dois domínios, isto é, se precisamos de uma teoria que descreva quais são os mecanismos pelos quais os indivíduos considerados como sujeitos se identificam (ou não se identificam) com as 


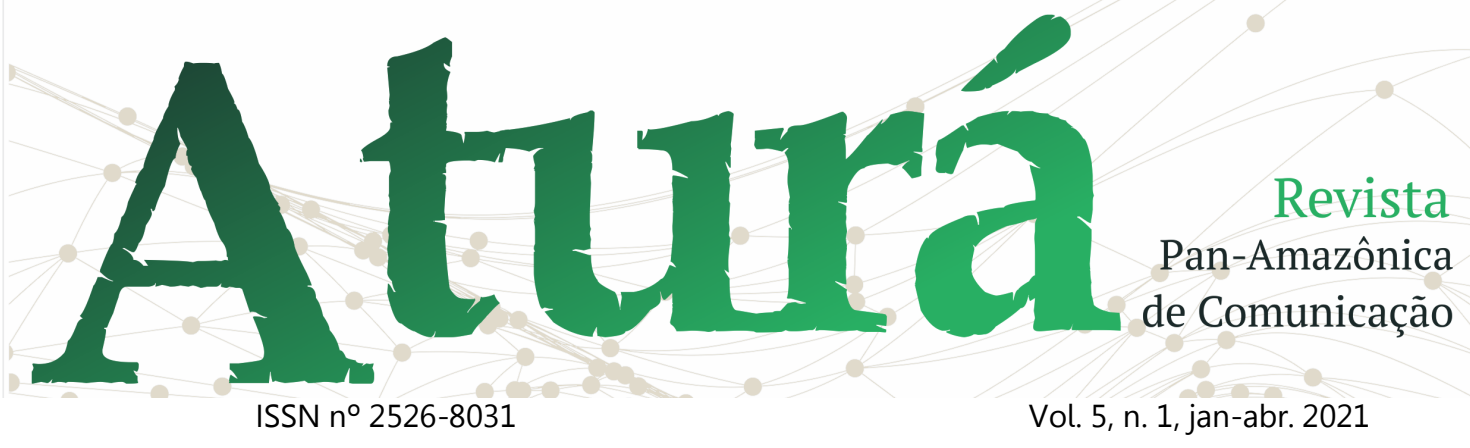

"posições" para as quais são convocados; que descreva de que forma eles moldam, estilizam, produzem e "exercem" essas posições; que explique por que eles não o fazem completamente, de uma só vez e por todo o tempo, e por que alguns nunca o fazem, ou estão em um processo constante, agonístico, de luta com as regras normativas ou regulativas com as quais se confrontam e pelas quais regulam a si mesmos - fazendo-lhes resistência, negociando-as ou acomodando-as [...] (HALL, 2013, p. 126)

Nesse sentido, Escosteguy (2010, p. 155) identifica que "duas posições passam a ser cruciais nesse contexto: a disposição de viver com a diferença e, de outro lado, a etnicidade". Mas, o que seria o termo etnicidade? Escosteguy explica que o termo se concentra no espaço da história, da linguagem e da cultura criando um sentimento de pertencimento a partir das diferenças, na construção da subjetividade e da identidade.

Por meio da prática discursiva da reportagem, fica clara a intenção de promover um sentimento de solidariedade, que se dá por meio dos sentidos do produto cultural. Quer sejam eles de inclusão da pessoa com deficiência, quer sejam de negativa ao preconceito existente frente a parcela da sociedade que possui algum tipo de deficiência física ou mental.

Ao fazermos uma analogia com o pensamento de Hall (2003), quando ele faz uma abordagem que instiga a adoção de estratégias para erradicação do racismo, a exclusão e a inferiorização, as medidas para acabar com o preconceito contra as pessoas com deficiência seguem a mesma linha. Hall (2003, p. 88) entende que a liberdade individual e igualdade formal, entendida como "igualdade de mérito", não podem fornecer "os elos de reconhecimento, reciprocidade e conexão que dão significado a nossas vidas enquanto seres sociais".

Assim, o processo comunicacional precisa construir uma empatia em que 0 outro se veja no diferente, como precondição para a legitimidade do que Hall classificou como "a identificação de todos".

\section{Respeito às diferenças: mínimo que a vida em sociedade exige \\ Produzido em julho de 2018, o documentário $A$ intolerância que mata, do jornalista Rubens Medeiros, evidencia a}




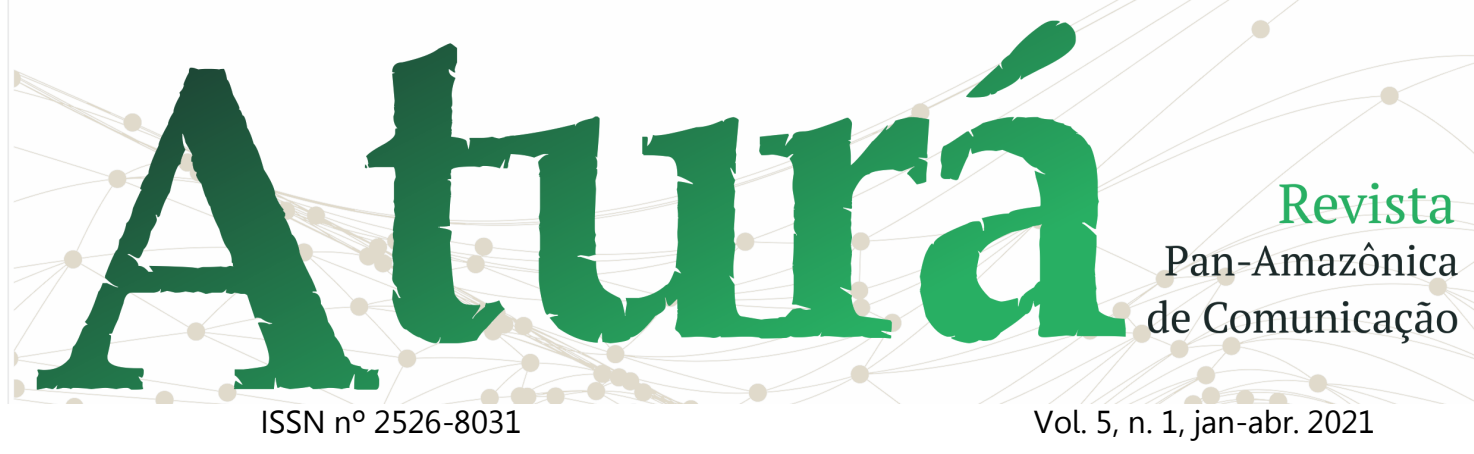

triste realidade que a população LGBT enfrenta diariamente em Roraima. Com duração de 38 minutos e 29 segundos, a reportagem apresenta entrevistas com travestis, transsexuais, gays, membros do Conselho Estadual LGBT e dados sobre os índices de violência desse segmento. A película traz ainda o papel da família e das instituições públicas no combate à discriminação.

Aí, minha princesa, eu ainda the espero. Você não desanime que eu ainda te quero. Você não imagina o quanto estou sozinho, sem ver sua presença estou aqui morrendo. Não tem remédio que cure, o remédio é ver você. Você chegando aqui ainda vou viver. Tenha dó de mim, venha aqui me ver."

A música é de pai para filha. O relato de quem viu um filho sair pela porta de casa e voltar mulher, meses depois. Houve dor, revolta, mas o amor e o sangue falaram mais alto. Aos 71 anos, o agricultor nunca tinha ouvido falar na palavra "transexual". Quando tomou conhecimento, foi pela filha, Kelly (A INTOLERÂNCIA QUE MATA, 2018 , n.p).

A partir desse momento, iniciam-se os relatos de quem conviveu e precisa conviver diariamente com o preconceito. Kelly Sales fez magistério. Sonhava em ser professora. Mas nunca conseguiu entrar em uma sala de aula para praticar o que aprendeu. O preconceito é constante. Mas ela conta que vencer diariamente a subalternidade the garantiu a sobrevivência. Esse posicionamento, no pensamento de Bhabha (1998), ocorre a partir do momento em que o outro (subalterno) tem consciência de que é oprimido.

Essa forma de narrativa se assemelha à ideia proposta pelos estudos pós-coloniais, que é desconstruir a formação discursiva colonialista e fomentar a construção de novas subjetividades.

Nesse momento 'pós-colonial', os movimentos transversais, transnacionais e transculturais, inscritos desde sempre na história da "colonização", mas cuidadosamente obliterados por formas mais binarias de narrativização, têm surgido de distintas formas para perturbar as relações estabelecidas de dominação e resistência inscritas em outras narrativas e formas de vida. Eles reposicionam e deslocam a "diferença" sem que, no sentido hegeliano, se atinja sua "superação". Shohat observa que a ênfase antiessencialista do discurso "póscolonial" por vezes parece constituir uma tentativa qualquer de recuperar ou inscrever o passado comum como uma forma de idealização, a despeito de sua relevância enquanto local de resistência e identidade coletiva (HALL, 2003, p. 114).

A resistência, nesse contexto, é residual e emergente, frente aos discursos de representação e poder. O indivíduo 


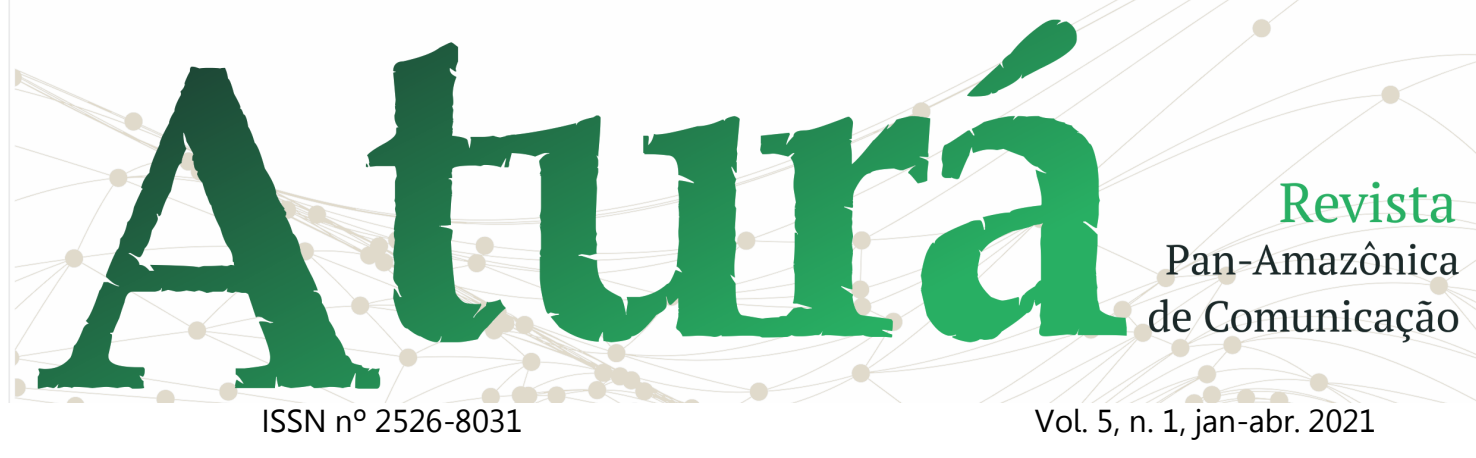

assume um movimento de voz certamente, é uma fomentadora do contestadora e formula suas próprias preconceito.

narrativas. Ou seja, conta sua própria ideia e história.

A reportagem mostra a importância do engajamento da Associação de Travestis, Transexuais e Transgêneros do Estado de Roraima, Grupo Diversidade e Conselho Estadual LGBT como portavozes em defesa de algo comum entre todos, independentemente da orientação ou designação sexual: cidadania e direitos humanos.

O processo de representatividade de classe inclui identificar os vitimados por questões relacionados à raça, a gênero ou à classe. Essa metodologia ajuda o sujeito a ter consciência de que é oprimido, a refletir seu lugar de fala e, consequentemente, mobilizar outros contra a opressão.

O jornalista Rubens Medeiros, na construção do documentário, ouviu especialistas na área da psicologia, entendendo assim, nesta análise, ser uma estratégia para desmistificar e romper estereótipos e educar para o fim da homofobia. A falta de conhecimento,

O estereótipo não é uma simplificação porque é uma falsa representação de uma dada realidade. É uma simplificação porque é uma forma presa, fixa, de representação que, ao negar o jogo das diferenças (que a negação através do Outro permite), constitui um problema para a representação do sujeito em significações de relações psíquicas e sociais (BHABHA, 1998, p. 117).

Nessa linha, para Bhabha (1998), o que se nega é o acesso "ao reconhecimento da diferença". O póscolonial segue o raciocínio de que na sociedade contemporânea, há uma supervalorização do saber científico. Mas o valor essencial deve estar nas experiências, nos relatos, falas e nas representações simbólicas dos povos subalternos.

Desse modo, como superar a barreira do preconceito e discriminação e, com isso, caminhar para a igualdade e direitos a diferença? O universalismo abstrato da modernidade não representa concretude ao anunciado, mas a interculturalidade que contemple as diferenças vinculadas a uma plataforma de direitos humanos em constante 


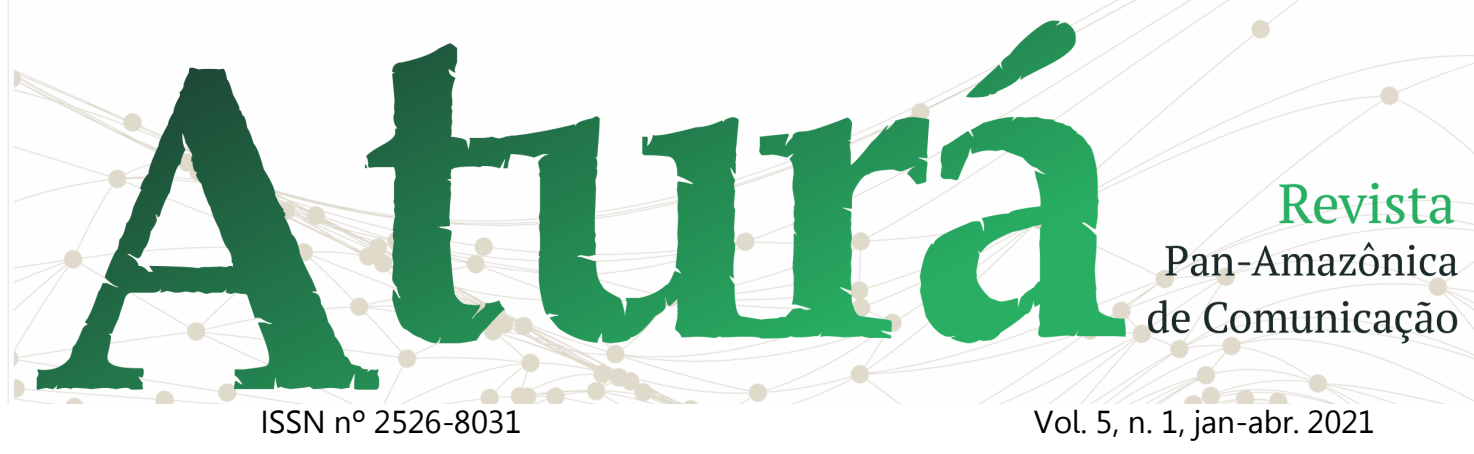

construção, que incorpore os valores e Considerações finais

demandas das comunidades diaspóricas, pensamos ser possíveis resultados e transformações. As políticas públicas fazem parte dessa plataforma.

Em 2010, a Assembleia Legislativa de Roraima aprovou a Lei 796, que assegura às pessoas transexuais e travestis a identificação pelo nome social em documentos e quando atendidas nos órgãos da administração pública estadual direta e indireta. Pode parecer pouco, mas só quem tem 35 anos de serviço público, sendo chamada diariamente pelo nome civil, sendo ridicularizada perante os colegas, sabe a diferença que isso faz na vida. A Assembleia Legislativa de Roraima também aprovou duas leis, há mais de dez anos, para a prevenção e controle do vírus HIV, em Roraima. A Lei 483 de 2005 dispõe sobre medidas sanitárias a serem adotadas em estabelecimentos públicos e privados para evitar a proliferação do vírus. Já a Lei 562 de 2006, determina a veiculação de programas de informação e prevenção contra a aids aos alunos dos ensinos fundamental e médio, aqui no Estado (A INTOLERÂNCIA QUE MATA, 2018, n.p).

A estratégia é educar o outro. Valorizar a subjetividade e o respeito às diferenças. Estas, por sua vez, surgem não para fragmentar e, sim, como mecanismos de resistência das minorias e dos excluídos. Os meios de comunicação, na conjuntura ora apresentada pela TV Assembleia de Roraima, podem funcionar como eco dessa resistência.

A partir da produção midiática, no caso desta pesquisa, os documentários Limitado, eu? e $A$ intolerância que mata, a TV Assembleia Legislativa de Roraima constrói uma identidade em sintonia com as atribuições de uma emissora institucional. O veículo assume um papel de protagonista na produção e disseminação de um discurso político e inclusivo diante da problemática apresentada nas reportagens sobre os desafios diários da pessoa com deficiência, com destaque para sua inserção no

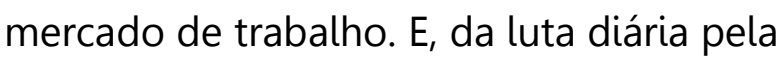
garantia dos direitos da população LGBT e o fim da homofobia.

Os Estudos Culturais explicam essa construção identitária como resultado das práticas sociais no processo comunicacional, em que os significados são instituídos pela sociedade, como uma visão de si mesma. Nesse sentido, o Poder Legislativo, por meio de sua TV institucional, contribui para a quebra de paradigmas do preconceito contra as pessoas com deficiência e população LGBT, mas também os próprios 


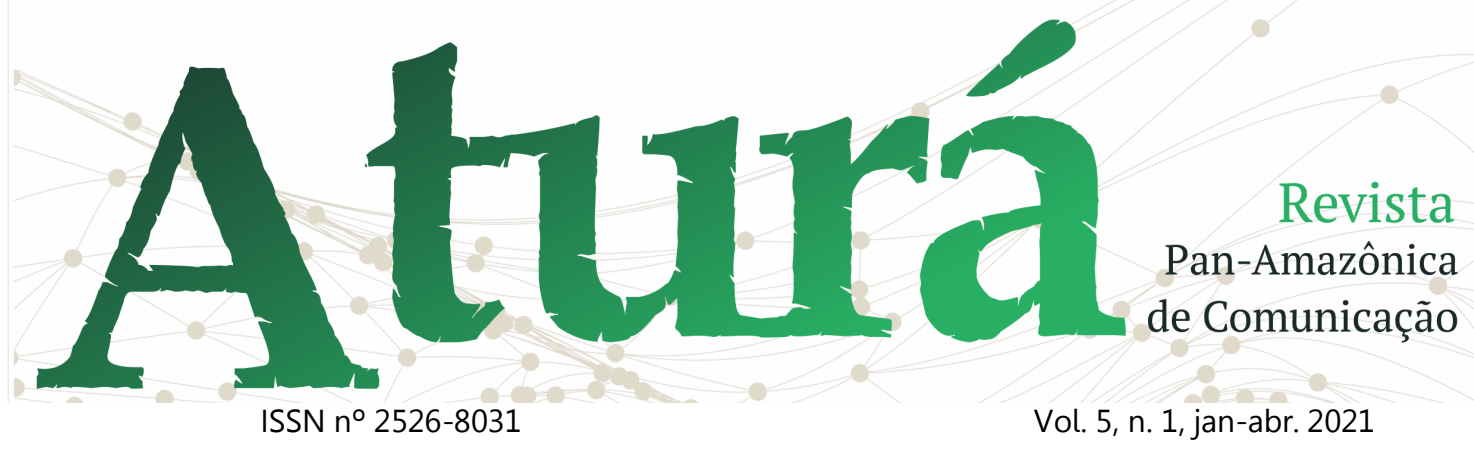

personagens entrevistados nos Referências

documentários reforçam que a limitação, os preconceitos e discriminação não estão nos subalternos.

A problemática está na falta de elaboração e execução de políticas públicas que possam realmente promover a inclusão social. De medidas que protejam o outro e as diferenças. A esse, pode-se classificar como afloramento do sentimento de solidariedade e empatia, sugerindo dessa forma a inserção "das minorias" no contexto político, econômico e social sem estranhamento das diferenças que vão além do imaginário social.

Nesse sentido, a luta por equidade é papel de todos. Muito mais no atual cenário político, onde o representante máximo do povo brasileiro é propulsor de discursos que fomentam a superioridade e discriminação, seja social, racial ou de gênero. Os meios de comunicação se tornam ferramentas importantes na desconstrução do negacionismo e fortalecimento do exercício da cidadania.

A INTOLERÂNCIA QUE MATA. Direção e Produção de Rubens Medeiros. Boa Vista: ALE, 2018. Disponível em: https://www.youtube.com/watch?v=y51b PqQI7nU\&list=PLYcvF7xgvWBH64kt9EA6 kLF7eA4hzfPqS\&index $=18$. Acesso em: 23 jul. 2020.

BARDIN, Laurence. Análise de Conteúdo. São Paulo: Edições 70, 2016.

BHABHA, Homi K. O Local da Cultura. Belo Horizonte: Editora UFMG, 1998.

BRASIL. (Constituição da República de 1988). Constituição da República Federativa do Brasil. Senado Federal: Brasília, 2017.

BRASIL. LEI No 13.146, DE 6 DE JULHO DE 2015. Institui a Lei Brasileira de Inclusão da Pessoa com Deficiência (Estatuto da Pessoa com Deficiência). Disponível em: http://www.planalto.gov.br/ccivil_03/_ato 2015-2018/2015/lei/l13146.htm. Acesso em: 22 jan. 2021.

ESCOSTEGUY, Ana Carolina D. Cartografias dos estudos culturais - Uma versão latinoamericana. Belo Horizonte: Autêntica, 2010.

ESCOSTEGUY, Ana Carolina D. As relações de gênero nos estudos de recepção: notas sobre metodologias de pesquisa e suas repercussões teóricas. Anais da Sociedade Brasileira de Estudos Interdisciplinares da Comunicação. Intercom. 2002. Disponível em:

http://www.intercom.org.br/papers/nacio 


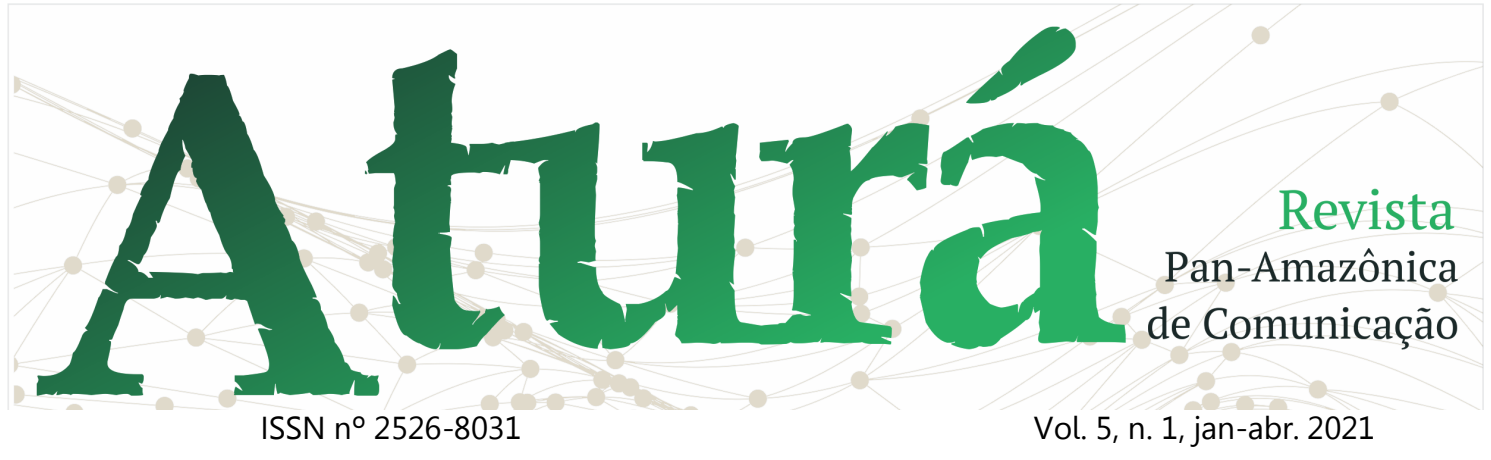

nais/2002/Congresso2002_Anais/2002_NP 13ESCOSTEGUY.pdf. Acesso em: 13 jul. 2020.

FACCHINI, Regina. Histórico da luta de LGBT no Brasil 2011. Psicologia e diversidade sexual./Conselho Regional de Psicologia da $6^{\text {a }}$ Região - São Paulo: CRPSP, 2011. Disponível em: http://www.crpsp.org.br/portal/comunica cao/cadernos_tematicos/11/frames/cader no_tematico_11.pdf. Acesso em 14 de jan. 2021.

Disponível em https://www.youtube.com/watch?v=9kXD 6Hj7_Qk\&list=PLYcvF7xgvWBH64kt9EA6k LF7eA4hzfPqS\&index $=5$. Acesso em: 23 jul. 2020.

MARTíN-BARBERO, Jesús. Dos meios às mediações: comunicação. cultura e Hegemonia. Rio de Janeiro: Editora UFRJ. 1997.

PINTO, Milton José. Comunicação e Discurso. São Paulo: Hacker Editores. 2002.

HALL, Stuart. Da Diáspora: Identidades e mediações culturais. Belo Horizonte: Editora UFMG; Brasília: UNESCO, 2003.

HALL, Stuart. Quem precisa de identidade? In: SILVA, Tomaz Tadeu da. (org.). Identidade e diferença: a perspectiva dos Estudos Culturais. Rio de Janeiro: Vozes. 2013.

HOHLFELDT, A.; MARTINO, L.C.; FRANÇA, V.V. Teorias da Comunicação: conceitos, escolas e tendências. Petrópolis, RJ: Vozes, 2001.

LOPES, Maria Immacolata Vassallo de. Mediação e recepção. Algumas conexões teóricas e metodológicas nos estudos latino-americanos de comunicação. Anais do Congresso da IAMCR, Dublin, Irlanda, $2013 . \quad$ Disponível em: http://www.revistas.usp.br/matrizes/articl e/view/82931/85965. Acesso em: 13 jul. 2020.

LIMITADO, EU?. Direção e Produção de Rubens Medeiros. Boa Vista, 2018. 